\title{
Determinants of Career Intentions of Accounting Students
}

\author{
Newman Amaning ${ }^{1}$, Reindolph Osei Anim ${ }^{2}$, Alexander Kyere ${ }^{3} \&$ Godfred Peprah-Amankona ${ }^{4}$ \\ ${ }^{1}$ Lecturer of Accounting, Sunyani Technical University, Sunyani, Ghana \\ ${ }^{2}$ Lecturer of Accounting and Finance, Christian service University College, Kumasi, Ghana; \\ ${ }^{3}$ Director of Internal Audit, Koforidua Technical University, Koforidua, Ghana \\ ${ }^{4}$ Finance Directorate, Sunyani Technical University, Sunyani, Ghana \\ Correspondence: Newman Amaning, Sunyani Technical University, Sunyani, Ghana.
}

Received: October 28, 2020

Accepted: November 20, 2020

Online Published: November 24, 2020

doi:10.5539/ibr.v13n12p14

URL: https://doi.org/10.5539/ibr.v13n12p14

\begin{abstract}
This study examines the determinants of accounting students' career intentions. The study adopted survey questionnaires developed on a 5-point Likert's scale to collect primary data from 231 final year university students pursuing accounting across Ghana using purposive sampling technique. The study employed the use of PLS-SEM to conduct Regression Analysis. The outcome of the study reveals that the relationship between the future plan and career intentions of accounting students is significantly positive, and a positive perception on the accounting profession influences the accounting student to pursue a career in accounting. Thus, future plans and students' perception on professional examinations influence the career intentions of the accounting students in Ghana. The study recommends that future studies should explore the effects of other important variables including race, culture, religion, marital status, etc. on the career intentions of accounting students.
\end{abstract}

Keywords: determinants, career intentions, accounting profession, professional accounting examination, students, theory of planned behaviour

\section{Introduction}

It is public knowledge that a lot of career opportunities exist within the accounting profession (Cooper et al., 2020; Bekoe et al., 2018; Anderson-Gough, 2002). These include audit, tax, financial reporting, business advisory, etc. It is, however, erroneous to conclude that all accounting students after graduation will consider building a career within the accounting profession. This is mainly because the economy lacks the requisite number of qualified staff. In Ghana for instance, according to the Institute of Chartered Accountants, Ghana (ICAG), the sole statutory regulatory body set up by an Act of Parliament, Act 170, to regulate the accounting profession in the country, as at September, 2020, the number of qualified accountants in Ghana were less than 6000 (http://www.icag.com/). This figure is woefully inadequate considering the status of the country as an emerging market that requires the critical role of the accountant to help propel its growth. This phenomenon has led to growing concerns about the number of students who fail to enroll for professional accounting examinations after graduation (Felton et. al., 1995).

The accounting profession has witnessed several changes as a result of globalization (Bourn, 2018). More so, the corporate financial malfeasances that engulfed firms in Europe and the United States (US), have led to challenges to the integrity, professional conducts, and responsibility of the accountant to the public. The reforms that have taken place after these numerous scandals have contributed to ensuring the reputation and professionalism of the accounting profession. To ensure that accounting students are equipped to meet the expectations of the public after completion and graduation, they must be prepared to embrace the changes brought about by globalisation and their associated challenges.

Prior studies such as (Amani \& Mkumbo, 2016; Suan, Mat \& Tan, 2012; Jones, Paretti, Hein \& Knot, 2010) have concluded that a lot of determinants influence the career choice of an individual. For instance, Suan, Mat and Tan (2012) posit that the financial benefits associated with the job are one of the key variables considered by students in opting for a career. According to Amani and Mkumbo (2016), students also consider their family background before making career choices. In Japan, Sugahara, Hiramatsu, and Boland (2009) posit that education and experience influence students' career intentions to become professional accountants. In China, 
Wen, Hao, and $\mathrm{Bu}$ (2015) argued that the influence of parents, teachers, and friends have an impact on the career choice of accounting students. Jackling and Calero (2006) concluded that the accounting teacher has a critical role to play in shaping the mindsets of students in their quest to make career choices. Within these contexts, various factors, both intrinsic and extrinsic, influence the student in deciding which career to pursue in the accounting profession.

There are limited studies on the determinants of the career intentions of accounting students in Sub Sahara Africa. For instance, in Tanzania, Amani and Mkumbo (2016), examined the predictors of career intentions among undergraduates. Similarly, in Nigeria, Bello (2019) investigated the relationship between accounting students' self-efficacy beliefs outcome expectations on the intention to become chartered accountants. Then in Ghana, Mbawuni and Nimako (2015) modelled job-related and personality predictors of intention to pursue accounting careers among undergraduate students. It must be emphasised that the results of these studies are fragmented as they were conducted on limited scales. For instance, Mbawuni and Nimako (2015) concentrated their study on only one university in Ghana. Again, the outcome of research is varied. This is the crux of the research gap. The researchers want to address this paucity by using a cross-section of final year accounting students in Ghana from both private and public universities. This study thus seeks to explore the determinants of the career intentions of the Ghanaian accounting students.

\section{Literature Review}

\subsection{Theoretical Framework}

Several studies have made use of several models and theories to explain accounting students' career intentions. These theories include the Theory of Reasoned Action (TRA) (Law, 2010), Theory of Planned Behaviour (TPB) (Srirejeki et al., 2019; Santos, 2018; Amani and Mkumbo, 2016; Mbawuni and Nimako, 2015; and Social Cognitive Theory (SCT) (Bello (2019). This study adopts the TPB as a fundamental theory. TPB is an offshoot of TRA that was developed by Martin Fishbein and Icek Ajzen in 1975.TPB has been widely published as it is mostly used to explain the phenomenon of behaviour and attitude.

Primarily, this theory offers a basic framework to research into the intentions towards behaviours. TPB, accordingly posits that most significant predictor of an individual's behaviour is behavioural intention, which subsequently is affected by three variables. One, behavioural belief is the person's belief in the outcomes of behaviour. Two, normative belief is the belief in the normative expectations of others and the zeal to achieve these expectations. Lastly, control belief is the existence of things that approve or prevent the behaviour that will be exhibited and the severity of how high things that approve and prevent its behaviour. As a rule of thumb, the higher the favourable attitude and subjective norm with respect to a behaviour, and the greater the perceived behavioural control, the higher a person's intention to execute the expected behaviour. Thus, TPB postulates that attitude towards positive or negative behaviour is an antecedent of behavioural belief. As a result, normative beliefs will yield social pressure, but control beliefs will result in perceived control (Ajzen, 2002).

This study seeks to explore the predicators of the career intentions of accounting students in Ghana. This research adopted TPB as a basic theory to investigate the career intentions of the accounting students in the accounting profession. According to Wen et al. (2015), TPB is a well-known theory, as it has been widely published to offer explanations to the determination of behaviour. In this study, the three subsets of TPB, namely attitude, subjective norm, and perceived behavioural control are considered.

\subsection{Empirical Review}

Previous studies such as (Silfi \& Hamid, 2020; Rkein et al. 2019; Dilnot 2018).), have revealed that the popularity of professional accounting among university students is still high. According to Pratama (2017), several students have opted for accounting in their career decisions. Several studies such as (Pincus et al., 2017; Holt et al., 2017; Ng et al., 2017), posit that accounting profession is seen as one of the most preferred career paths by university students. Findings of prior researches such as gender differences (Ahmadi et al 1995; Omar, 2009), students' experience (Sugahara et al., 2008), salary considerations (Said et al., 2004), and students' mindset concerning professional examinations (Sugahara et al., 2008; Omar, 2009), reveal the interest of accounting students in professional qualifications. In a study conducted by several researchers such as (Wen et al., 2018; Owusu et al., 2018; Mustapha, \& Hassan, 2012), it was found that accounting students have future educational plans, plans for professional accounting qualifications, and plans of pursuing careers in accounting. The above interest notwithstanding, not many students have continued to pursue professional accounting examinations after graduation. Thus, this paper aims to appreciate the incoherence.

Many studies such as Germanou and Hasall. (2009), found that a positive perception of a student about the 
accounting profession influences his or her career intentions to seek a career in professional accounting. Studies such as Tan and Laswad (2018), Abbott and Palatnik (2018), and Sugahara and Bolland (2006) argue that some students hold the perception that the professional accounting programme requires low communications skills than an accounting degree programme. This perception tends to influence students in making career decisions in accounting. The findings show that students' positive mindsets about professional accounting examinations influence them to consider career aspirations in accounting. Perceptions are measured by four variables. These are extrinsic, intrinsic, prestige and social variables. Salary, job security and physical environment at the place of work denote extrinsic perception. Opportunities for promotion, status in the eyes of others, recognition and decision making represent prestige. Perceived prestige, according to Steadman and Huang (1996) and Wheeler (1983), are the positive perception of students from business, psychology, and education hold about accountants. They are of the view that the accountant is better than other professionals within the business cycle. And according to Ariail et al. (2020), whereas accountants have a positive outlook on the accounting profession, nonaccountants on the other hand have a negative perception about the profession. Jackling et al. (2012) found that prestige is an important factor in the career decisions of accounting students in pursuing professional qualifications. This conclusion is reinforced by several studies such as Mustapha and Hassan, 2012; Germanou and Hasall, 2009. The intrinsic variable is represented by the experience of learning new things, achieving a challenging task and the opportunity of being free from imposed restrictions in the work environment. According to Jackling, de Lange, Phillips and Sewell, intrinsic motivational factors drive students in Australia to pursue career opportunities in accounting. Social on the other hand stands for affective items. Owusu et al., (2018) and Sugahara and Bolland (2006), conclude that accounting students put a premium on promotion opportunities, high social prestige and high salary than nonaccounting students.

Results from previous researches conclude that salary is the single most significant factor that influences the accounting graduates' decision on career choices. Studies such as Said et at., (2004), posit that the initial salary is a prime predictor in opting for a professional accounting career. This finding is in agreement with Abdullah and Zakaria (2006) and Ghani et al. (2008). According to Ozsoy (2019), salary is a hygiene factor that motivates an individual to work. Other studies in support of this position include Harun (2020), who insists that the starting salary is the main criterion that influences the career choice of students. Demel et al., (2019) also posit that the initial salary is a significant predicator of career interests in the accounting profession by accounting students. Nonetheless, studies such as Cottrel (2011) argues that the initial salary, although considered a significant criterion in career decisions of accounting graduates, but with time, other factors tend to override this importance. Accordingly, Mustapha and Hassan (2012) and Law (2010) disagree that salary is a significant variable motivating students to pursue a career as professional accountants.

The opportunity to advance in the accounting profession is another variable that influences the career decisions of accounting students. Cohen et al., (2020), observe that opportunities for advancement are better in accounting fields as compared to other professions. These opportunities propel them to rise above challenges to prove that they can live up to expectations on the job. Said et al. (2004), in their study in Malaysia observe that this factor significantly influences the career decisions of accounting students. Mustapha and Hassan (2012) agree with this finding by positing that opportunities to advance on the job is positively correlated to students' career choice as professional accountants. Samsuri et al. (2016) posit that the opportunity to advance on the job is the main reason why undergraduate female students pursue accounting. Trump and Hendrickson (1970), had earlier on arrived at a similar conclusion. The opportunity to advance on the job, according to them is among the first two criteria in the career decisions of students. However, Marriot and Marriott (2003) hold a divergent view. They believe that students pursuing accounting have very low career prospects.

Deficiency of information and sometimes misinformation on what accountants do in practice consist of some other factors that influence the career decisions of students. And according to Omar (2009), students, among the factors that usually affect their career ambitions, is their perception towards the profession. Some students, Omar (2009), posits have a misconception about accounting; that it is difficult and extremely impossible to pass the professional accounting programme and that only a few can pass in only one sitting. Malthus and Fowler (2009), agree with this finding. In their study carried out in New Zealand, Malthus and Fowler (2009, report that students at tertiary level and high school teachers see accounting to be dull and boring. Hunt et al. 2004; Heiat et al. 2007, reinforce this position. Some other misconceptions of students about the accounting profession are; accounting is a dull course and accountants are introverts (Țicoia \& Albu, 2018), and antisocial without a sense of humour (Smith, 2017), always busy with calculating figures behind their desks (Rocher et al. 2020; Jackling and Calero 2006) and compliant driven (Ishaque, 2020; DeFond et al., 2018). Despite the fact previous studies have concluded that the accounting profession is deemed to be dynamic and require personalities with creativity and 
critical thinking skills, very little progress has been made to dispel these misconceptions about the profession. The available empirical studies show that negative stereotyped opinion on the professional accountant appears to prevail and that this perception could deter many students from pursuing a career in professional accounting. The accountant is seen as methodical, structured, boring, antisocial and many other stereotypes.

Despite the factor that the skills expected of the modern-day professional accountant dispute such stereotypes, the enquiry is whether students aspiring to be chartered accountants will have such stereotyped perceptions about the profession. This tends to attract an inappropriate category of people into the profession or the appropriate type of people not opting for the profession. According to Tourna-Germau (2006), negative images towards the accounting profession has adversely affected the enrollment of skilled and people-oriented personalities that are prerequisites of the accounting profession. Students also have the opinion that professional accounting programmes are more difficult than academic programmes. Thus, it is suitable solely for disciplined, cognitively brilliant, and highly committed students. Hence some students are of the notion that it is better they pursue other programmes instead of professional accounting programmes. This perception is mainly influenced by the misconception about the number of sittings that most professional accounting students are required to make before they can become chartered accountants. Accordingly, this misconception has affected the attitude of students towards the professional accounting qualification. Other studies also examined if the opinion of students about accountants' changes during schooling at the university. Herbert et al., (2020), in their study, found varying views about students pursuing accounting and others without career aspirations and interest in accounting. They report that students with a career interest in accounting place much premium on the need for interpersonal skills. At the commencement of their course, students held a positive attitude about accounting as a profession (Wyness \& Dalton, 2018).

Nevertheless, this perception reduces materially by the end of the course. The students perceive accounting as less interesting and the possibility of securing employment as accountants upon completion as extremely bleak. Thus, students have a less positive interest in the accounting profession at end of their studies than at the beginning. The gender of the accounting student also can influence the preference of career choice in accounting and thus the desire to pursue a professional accounting programme. Previous studies such as (Khattab \& Modood, 2018; Haynes, 2017). posit that male accounting students, unlike their female counterparts, perceive accounting profession as more interesting with a higher degree of interaction. These findings are consistent with the position of Sugahara and Bolland (2006), who report that the accounting profession is significantly male-dominated. Woasey (2015), opines that apart from extrinsic and intrinsic factors, another variable that significantly influences students' aspirations in pursuing professional qualification is the cost involved. This finding is consistent with a report issued by CASP in 2014 which cites that a major factor deterring students from pursuing professional accounting qualification is the huge cost involved. These studies imply that the cost involved in pursuing a professional qualification in accounting negatively impact on the aspirations of graduates in becoming chartered accountants.

Mustapha and Hassan (2012) postulate that job security and stability are significant variables in the career decision of the prospective professional accountant. Abdullah and Zakaria (2006) had earlier on made similar observation that job security is an important attribute for accounting students in their quest to pursue a career with public accounting firms (Uthman et al., (2019). Majority of students perceive professional accounting qualification as the surest avenue of securing employment opportunities. Accordingly, Thing and Jalaludin (2018) posit that students opt for the availability of job opportunities as the most significant benefit of pursuing a career as a professional accountant. Job security and stability is seen as a factor that is of concern to female accountants Cimirotić et al. 2017). These conclusions are however inconsistent with to the observations made by $\mathrm{Ng}$ et al., (2017) who report that job security is not a major factor influencing the career aspirations of students.

According to Byrne et. al., (2012) and Law (2010), 'parental influence' and pieces of advice from parents, lecturers and others are other considerations that drive students to pursue professional accounting qualifications. According to these studies, pieces of advice from significant family members and influence of instructors at school are significant predicators influencing students' career intentions. Law (2010) reinforces this finding by positing that 'parental influence' greatly contributes in deciding the career decision of accounting students.

\section{Conceptual Framework}

Future plans and the perceptions of the accounting students towards professional accounting examinations, the independent variables, are considered by the researchers as the fundamental determinants of the career intentions of the accounting students in Ghana. A student with plans to pursue professional accounting examinations has the intention of becoming a chartered accountant. Similarly, positive perception about the professional accounting 
qualification by the accounting student will influence such student to consider a career in professional accounting. This has been shown diagrammatically below in figure 1 .

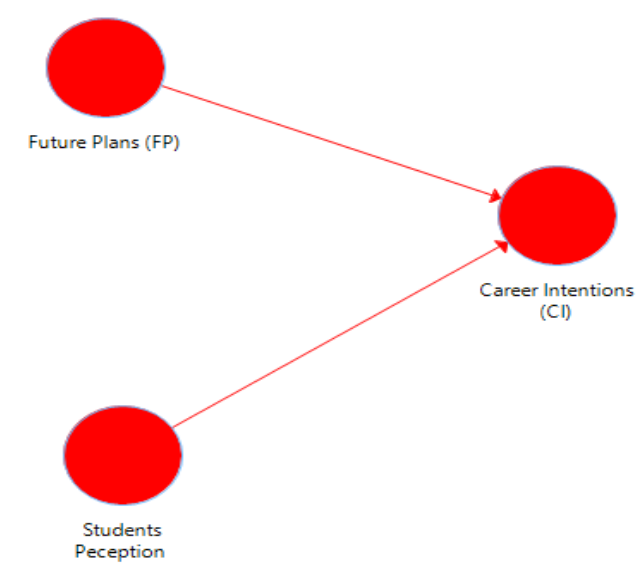

Figure 1. Conceptual Framework

Authors' construct

\section{Methodology}

\subsection{Study Design}

This study adopted a quantitative study design approach. The researchers used a survey method to investigate the factors influencing accounting students' career aspiration of becoming professional accountants. Due to the impact of the COVID-19 pandemic, an online survey was used in reaching the respondents chosen for the study as physical contact was not appropriate. This mode is also cost effective as compared to regular surveys.

\subsection{Population and Sampling}

The population of the study consist of final year undergraduate students pursuing accounting in Ghanaian tertiary institutions. Due to the nature of the study, the researchers adopted purposive sampling techniques in selecting the respondents for the research. This method ensured that the right respondents with the appropriate characteristics required for the study were selected. Accordingly, a sample size of 251 final year tertiary undergraduate students pursuing accounting was selected for the study. However, 231 questionnaires were completed and used for the research. The motives behind the choice of final year students are that they had spent a number of years in the university, and have gone through a sizeable number of significant accounting modules, they have a better and clearer perspective and expectations of their career choices. And unlike their counterparts in years 1,2 and 3, they would be deciding on their job selection within the shortest possible time.

\subsection{Data Collection and Analyses}

The data for the study which was primary was collected from the respondents through self-designed collection instrument was based on a 5 points Likert's scale questionnaire raging from strongly disagree to strongly agree and coded 1 to 5 respectively based on prior studies and adjusted to meet the study. The questionnaire was pre-tested to a sample of 15 students for modification to achieve a more reliable instrument. The researchers, due to the COVID-19 pandemic which made it impossible to reach the respondents through physical contacts, made use of online survey for this purpose. The questionnaire consists of four sections. Section A seeks information about the respondents' socio-demographics. Section B attempts to solicit the respondents' future plan after graduation, whiles Section C tries to obtain information about their perceptions of professional accounting qualifications. Section D seeks information about the accounting students career intentions after graduation.

The data collected were subsequently transformed into quantifiable numbers to assist in examining the research objective using a mix of descriptive and partial least squares structural equation modelling approaches (PLS-SEM). Subsequently, PLS-Algorithm (i.e. maximum iterations of 300 and a stop criterion of $10^{-7}$ ) and bootstrapping (i.e. using subsamples of 5000) were used to compute and analyse the study results. According to Chin (2010), PLS-SEM is most appropriate for the research because of the predictive focus of the study and the distribution free assumption of the PLS-SEM which was suitable for the research. 


\subsection{Model Specification}

The data gathered using the questionnaire designed for the study was the main source of information for the variables used for this paper. These variables are the prestige the professional accountant enjoys in the society; intrinsic motivation such as recognition on the job; job security; parental influence; cost involved in the pursuit of professional examinations; job security and stability; gender; misconceptions about the role and personality of the accountant; salary; and opportunities for career advancements and progressions considerations.

Reliability, validity, normality, and multicollinearity tests on the data gathered were conducted. The model adopted for this paper is:

$\mathrm{IPPE}=\alpha+\beta_{1} \mathrm{FP}+\beta_{2} \mathrm{SPPE}+\beta_{3} \mathrm{CI}+\varepsilon$

Where;

IPPE = Intention to Pursue Professional Examinations

$\alpha \quad=$ intercept

$\mathrm{FP} \quad=$ Future Plans

SPPE $=$ Students' Perception on Pursuing Professional Examinations

CI $=$ Career Intentions

$\varepsilon \quad=$ Errors

\section{Presentation of Results}

Results of PLS-SEM using PLS-Algorithm (i.e. maximum iterations of 300 and a stop criterion of $10^{-7}$ ) and bootstrapping (i.e. using subsamples of 5000) are reported in this section. The factor loadings were first estimated and in line with theory and previous literature, indicators with loadings below 0.7 were deleted (see Table 3 and Figure 1). Future plans had 6 indicators but 4 were retained, Career intentions had 9 indicators and 4 were deleted and last but not the least student's perception had 17 indicators but only 5 were retained for analysis. Starting with Table 1 which presents results of the correlations amongst the latent variables, a strong positive correlation exists between the dependent variable (i.e. career intentions) and the independent variables (i.e. future plans and students' perception). Also, a strong positive correlation $(\cong 75 \%)$ exists between future plans and students' perceptions. Although the correlation is quite strong, it does not meet the minimum threshold to cause multicollinearity problems in the model.

Table 1. Correlation Matrix of Latent Variables

\begin{tabular}{cccc}
\hline Variable & CI & FP & SP \\
\hline CI & 1.000 & & \\
FP & 0.749 & 1.000 & 1.000 \\
SP & 0.704 & 0.747 & \\
\hline
\end{tabular}

Note: $C I=$ Career Intentions; $F P=F u t u r e$ plans; $S P=$ Students Perception

The internal consistency of the responses was assessed using both composite reliability and Cronbach's alpha. According to Hair et al. (2017), Cronbach's alpha (CA) is considered as the lower bound while composite reliability (CR) is considered the upper bound of the test and should be higher than 0.70. From the results presented in Table 2, both Cronbach's alpha and composite reliability values are above 0.7 . Hence, the responses considered reliable. Also, all the values of Average Variance Extracted (AVE) ${ }^{1}$ shown in Table 2 are higher than 0.5 an indication that the responses are valid. To check for the presence or otherwise of collinearity problem, the variance inflation factor (VIF) was estimated and the results for both the inner VIF (see Table 2) and outer VIF (see Table 3) values are reported. The rule of thumb is the VIF value should be lower than 5 (Hair et al., 2017). From Table 3, all the VIF values are below 0.5, therefore, we conclude that collinearity problem(s) is absent in the model.

\footnotetext{
${ }^{1}$ Average variance extracted (AVE) is a criterion for assessing convergent validity
} 
Table 2. Test of Reliability and Validity Results

\begin{tabular}{|l|c|c|c|c|}
\hline & CA & CR & AVE & VIF (INNER) \\
\hline CI & 0.888 & 0.918 & 0.693 & 2.263 \\
\hline FP & 0.942 & 0.959 & 0.853 & 2.263 \\
\hline
\end{tabular}

Note: $\mathrm{CI}=$ Career Intentions; $\mathrm{FP}=$ Future plans; $\mathrm{SP}=$ Students Perception; $\mathrm{CA}=$ Cronbach's Alpha; AVE $=\mathrm{Average}$ Variance Extracted; VIF= Variance inflation factor

Table 3. Results of Factor Loadings and Variance Inflation Factor

\begin{tabular}{|c|c|c|}
\hline INDICATOR & LOADING & VIF \\
\hline $\begin{array}{l}\text { 1. The prestige the professional accountant enjoys in the society motivates me to become a } \\
\text { chartered accountant after graduation (CI1) }\end{array}$ & 0.906 & 3.340 \\
\hline $\begin{array}{l}\text { 2. Intrinsic variables such as experience of learning new things, achieving a challenging task } \\
\text { and the opportunity for making independent decisions on the job drive me to become a } \\
\text { chartered accountant after graduation (CI2) }\end{array}$ & 0.902 & 3.474 \\
\hline $\begin{array}{l}\text { 3. 'Parental influence' and pieces of advice from parents, lecturers and others motivate me to } \\
\text { pursue professional accounting qualifications afC13) }\end{array}$ & 0.779 & 1.960 \\
\hline $\begin{array}{l}\text { 4. The huge cost involved in pursuit of professional accounting qualification does not deter me } \\
\text { from aspiring to become a chartered accountant after graduation (CI5) }\end{array}$ & 0.790 & 2.087 \\
\hline $\begin{array}{l}\text { 5. Availability of career advancements on the job motivates me to become a chartered } \\
\text { accountant after graduation (CI8) }\end{array}$ & 0.774 & 1.914 \\
\hline 6. I have plans of pursuing further studies in accounting (FP1) & 0.926 & 4.407 \\
\hline 7. I have an intention of pursuing professional accounting qualification after graduation (FP2) & 0.933 & 4.430 \\
\hline 8. Professional accountant will be my prime priority in my career choice decisions (FP4) & 0.927 & 4.126 \\
\hline 9. I have already decided on which professional accounting qualification to pursue (FP5) & 0.907 & 3.483 \\
\hline 10. Professional accounting examination is challenging (SP17) & 0.727 & 1.860 \\
\hline $\begin{array}{l}\text { 11. Accountants with professional qualifications are more respected than accountants with a } \\
\text { degree in accounting (SP2) }\end{array}$ & 0.868 & 2.694 \\
\hline $\begin{array}{l}\text { 12. Professional accountants have better opportunities for promotions to high level positions in } \\
\text { organisations (SP5) }\end{array}$ & 0.849 & 2.834 \\
\hline 13. Professional Accounting field guarantees brighter future opportunities (SP6) & 0.903 & 3.662 \\
\hline 14. Professional Accounting is the very interesting professional field compared to others (SP7) & 0.843 & 2.555 \\
\hline
\end{tabular}




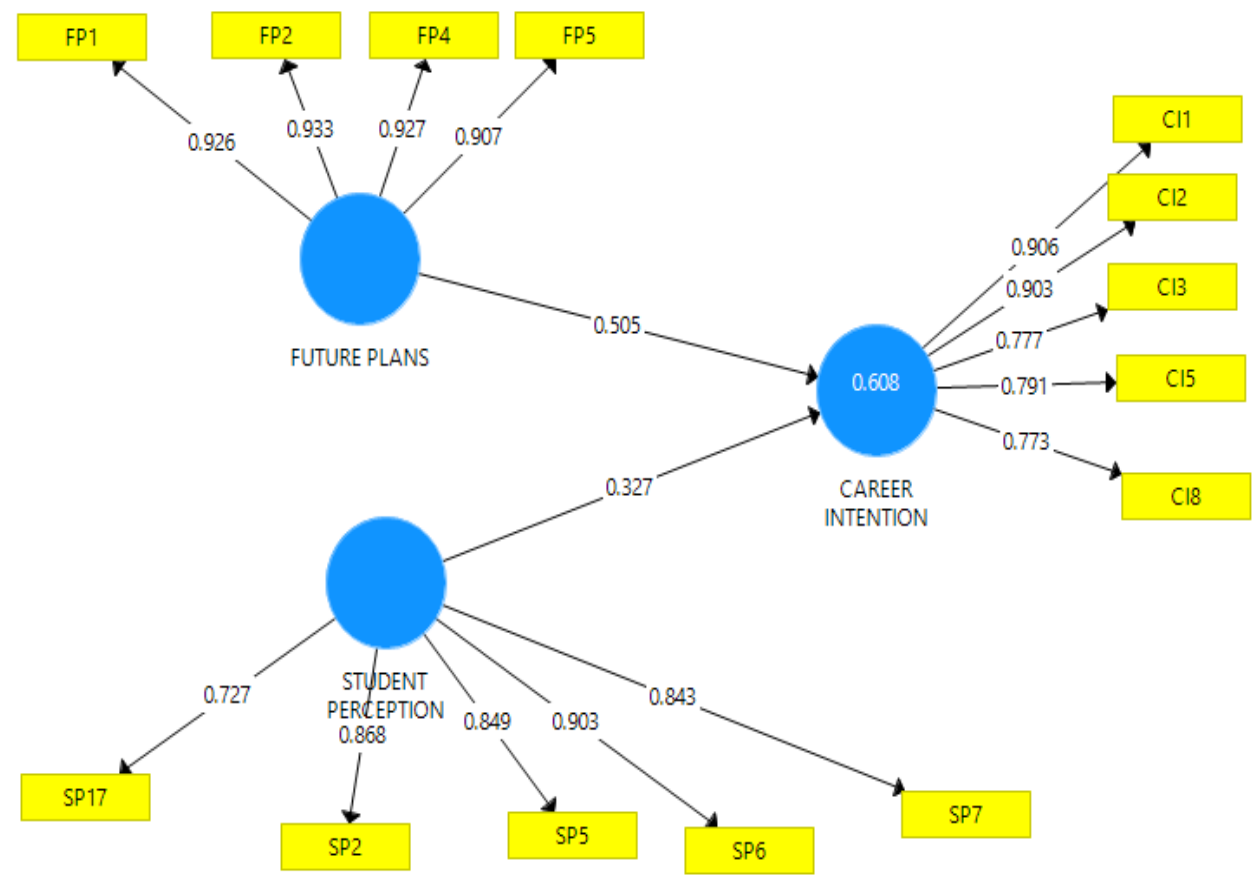

Figure 2. Path Model

Table 4. Results of Total Effects and Fit Indices

\begin{tabular}{lcccccc}
\hline & $\boldsymbol{\beta}$ & $\mathbf{M}$ & SD & T-Stat & P-Values & $\boldsymbol{f}^{2}$ \\
\hline $\mathrm{FP} \rightarrow$ CI & $0.505^{\mathrm{a}}$ & 0.498 & 0.085 & 5.977 & 0.000 & 0.288 \\
$\mathrm{SP} \rightarrow$ CI & $0.327^{\mathrm{a}}$ & 0.335 & 0.080 & 4.083 & 0.000 & 0.120 \\
Model Fit & & & & & & \\
$R^{2}$ & 0.608 & & & & & \\
$R^{2}$-Adjusted & 0.602 & & & & & \\
SRMR & 0.069 & & & & & \\
\hline
\end{tabular}

Note: $\mathrm{CI}=$ Career Intentions; FP=Future Plans; $\mathrm{SP}=$ Student Perception; $\beta=$ coefficient; $\mathrm{M}=$ Mean; T-Stat= T-Statistics; a denotes $1 \%$ significance level; $\mathrm{f}^{2}=$ effect size

The results of the impact of the independent variables on the dependent variable and the fit indices are presented in Table 4. The results show that a positive significant relationship exists between the future plan (FP) and career intentions (CI). A unit change in future plans of students will influence their career intention(s) by 0.505 in the same direction and it is significant at the $1 \%$ level. A positive relationship also exists between students' perception of professional examination and career intentions and it is statistically significant at a $99 \%$ confidence level. Thus, a unit change in students' perception of professional examination will result in 0.327 units change in their career intentions. The results have shown that both future plan and students' perception of professional examinations are significant determinants of students' career intention(s) in Ghana. Approximately $61 \%$ of the variance in the career intentions of students in Ghana is jointly explained by future plan and students' perception of professional examinations. However, the effect size of future plan is relatively higher (i.e. $f^{2}=0.288$ ) than the effect size of students' perception on professional examination (i.e. $\mathrm{f}^{2}=0.120$ ). Following the conventional approach, an SRMR value of below 0.08 indicates a good model fit. The estimated SRMR value in this study is 0.069 which is less than 0.08 and indication that this model is well fitted.

\section{Discussion and Conclusion}

This study aims to examine the career intentions of bachelor students in accounting. The outcome of this study is consistent with the conclusion of Germanou and Hassall (2009), that a positive perception of students concerning professional accounting qualification influences their career intentions to opt for the accounting profession. According to Germanou and Hassall (2009), the correlation between the perception of students and their career intentions in the accounting profession is significant. This position is replicated in this study (see Table 1). Again, from the study bachelor students of accounting in Ghana believe that there are favourable opportunities to advance on the accounting profession as compared to other professions. This conclusion is in agreement with 
several studies (see example Cohen et al., (2020; Thing \&Jalaludin, 2018; Mustapha \& Hassan, 2012). Thus, a positive perception of the accounting profession will cause a student to pursue a career in accounting. These perceptions with their resultant career intentions influence the bachelor student to have future plans after graduation. Results of the questionnaires administered show that accounting students in Ghana have:

"plans in pursuing further studies in accounting after graduation"

"intentions in pursuing professional accounting examinations after graduation" and

"already decided on which professional accounting examination to pursue after graduation". These plans indicate that bachelor students in Ghana consider career intentions in accounting as a topmost priority. This position is consistent with the conclusion of previous studies such as (Wen et al., 2018; Owusu et al., 2018; and Mustapha and Hassan, 2012).

The study outcomes suggest that the prestige the professional accountant enjoys in the society, intrinsic variables such as experience of learning new things, achieving a challenging task and the opportunity for making independent decisions on the 'parental influence' and pieces of advice from parents, lecturers and others, and availability of career advancements on the job, drive bachelor students in Ghana to consider career options in the accounting profession after graduation. Bachelor students in Ghana also are not perturbed by the huge cost involved in pursuing professional accounting examinations in their quest to consider career intentions in the accounting profession.

This paper contributes to the development of the subject matter of career decisions of undergraduates in Ghana, chiefly to examine the critical components in this approach; thus, to adopt models on social psychology in the field of accounting and to enhance the usage of PLS-SEM using SmartPLS software. Besides, the study outcomes contribute to the clarifications of variables that can influence significantly the accounting students' career intentions. Again, this study offers the information on how to stimulate the interest of students in the accounting profession.

This study recommends that accounting teachers and other stakeholders in accounting education offer the needed information and assistance to facilitate the career intention decision making of bachelor students in accounting.

\section{Limitations and Suggestions for Future Studies}

This paper has its weaknesses. The sample size is limited. This is mainly due to the fact that the study was conducted during the era of the COVID-19 pandemic, as universities and other tertiary institutions have been shut down by the governments. It is suggested that future studies should extend the sample size to include more respondents. This study was based on a quantitative study design approach. Although the adjusted R-squared of the regression result suggests that significant variations in the study variables are explained by the independent variables. However, important variables including race, culture, religion, marital status among others can be explored by future studies. Future studies should adopt a mixed research design approach to see if the same results would be arrived at. This study was based on Ghana and so was limited in scope. Future studies can explore cross country approach for the results to be compared.

Despite the limitations outlined above, this study offers a significant contribution to literature by serving as a source of information to accounting teachers, parents, tertiary institutions, professional examinations bodies of accounting and many others about the career intentions of the bachelor students.

\section{References}

Abbott, J. I., \& Palatnik, B. R. (2018). Students' perceptions of their first accounting class: implications for instructors. Accounting Education, 27(1), 72-93. https://doi.org/10.1080/09639284.2017.1381032

Abdullah, M., \& Zakaria, Z. (2006). Desired attributes of public accounting firms from accounting students perceptions: the case of University of Malaya \& International Islamic University of Malaysia. Journal of Financial Reporting and Accounting, 4, 2537. https://doi.org/10.1108/19852510680001582

Ahmadi, M., Helms, M. M., \& Nodoushani, P. (1995). A factor analytic approach profiling job selection differences of male and female accountants. Managerial Auditing Journal, 10(7), 17-24. https://doi.org/10.1108/02686909510147200

Ajzen, I. (2002). Perceived behavioral control, self-efficacy, locus of control, and the theory of planned behavior. Journal of Applied Social Psychology, 32(4), 665-683. https://doi.org/10.1111/j.1559-1816.2002.tb00236.x

Amani, J., \& Mkumbo, K. A. (2016). Predictors of career intentions among undergraduate students in Tanzania. Journal of Education and Human Development, 5(3), 106-15. 
Anderson-Gough, F., Grey, C., \& Robson, K. (2002). Accounting professionals and the accounting profession: linking conduct and context. Accounting and Business Research, 32(1), 41-56. https://doi.org/10.1080/00014788.2002.9728953

Ariail, D. L., Smith, K. T., \& Smith, L. M. (2020). Do American Accounting Students Possess the Values Needed to Practice Accounting? In Research on Professional Responsibility and Ethics in Accounting. Emerald Publishing Limited. https://doi.org/10.1108/S1574-076520200000023004

Bekoe, R. A., Owusu, G. M. Y., Ofori, C. G., Essel-Anderson, A., \& Welbeck, E. E. (2018). Attitudes towards accounting and intention to major in accounting: A logistic regression analysis. Journal of Accounting in Emerging Economies. https://doi.org/10.1108/JAEE-01-2018-0006

Bello, M. S. (2019). The Relationship between Accounting Students'Self-Efficacy Beliefs, Outcome Expectations on Intention to Become Chartered Accountants.

Bourn, D. (2018). The global engineer. In Understanding Global Skills for 21st Century Professions (pp. 201-219). Palgrave Macmillan, Cham. https://doi.org/10.1007/978-3-319-97655-6_9

Byrne, M., Willis, P., \& Burke, J. (2012). Influences on school leavers' career decisions- Implications for the accounting profession. The International Journal of Management Education, 10(2), 101-111. https://doi.org/10.1016/j.ijme.2012.03.005

Chin, W. (2010). How to write up and report PLS analyses. In Esposito Vinzi V, Chin W.W, Henseler J, Wang H (Eds.), Handbook of partial least squares: concepts, methods and applications. Springer Heidelberg, 655-690. https://doi.org/10.1007/978-3-540-32827-8_29

Cimirotić, R., Duller, V., Feldbauer-Durstmüller, B., Gärtner, B., \& Hiebl, M. R. (2017). Enabling factors that contribute to women reaching leadership positions in business organizations. Management Research Review. https://doi.org/10.1108/MRR-10-2014-0233

Cohen, J. R., Dalton, D. W., Holder-Webb, L. L., \& McMillan, J. J. (2020). An analysis of glass ceiling perceptions in the accounting profession. Journal of Business Ethics, 164(1), 17-38. https://doi.org/10.1007/s10551-018-4054-4

Cooper, L., Holderness, K., Sorensen, T., \& Wood, D. A. (2020). Perceptions of robotic process automation in public accounting. Available at SSRN 3445005. https://doi.org/10.2139/ssrn.3445005

Cottrell, T. (2011). Moving on: salaries and managing turnover. The Bottom Line. https://doi.org/10.1108/08880451111186044

DeFond, M. L., Zhang, J., \& Zhao, Y. (2018). Do managers successfully shop for compliant auditors? Evidence from accounting estimates. Evidence from Accounting Estimates. (November 27, 2018). European Corporate Governance Institute (ECGI)-Law Working Paper, (432). https://doi.org/10.2139/ssrn.3309678

Demel, S., Mariel, P., \& Meyerhoff, J. (2019). Job preferences of business and economics students. International Journal of Manpower. https://doi.org/10.1108/IJM-09-2017-0249

Dilnot, C. (2018). The relationship between A-level subject choice and league table score of university attended: the 'facilitating', the 'less suitable', and the counter-intuitive. Oxford Review of Education, 44(1), 118-137. https://doi.org/10.1080/03054985.2018.1409976

Felton, S., Dimnik, T., \& Northey, M. (1995). A theory of reasoned action model of the chartered accountant career choice. Journal of Accounting Education, 13(1), 1-19. https://doi.org/10.1016/0748-5751(94)00027-1

Fishbein, M., \& Ajzen, I. (1975). Intention and Behavior: An introduction to theory and research.

Germanou, E., \& Hassall, T. (2009). Students' perceptions of accounting profession: work value approach. Asian Review of Accounting, 17(2), 136-148. https://doi.org/10.1108/13217340910975279

Ghani, E. K., Said, J., Mohd Nasir, N., \& Jusoff, K. (2008). The 21st century accounting career from the perspective of the Malaysian university students. Asian Social Science, 4, 7383. https://doi.org/10.5539/ass.v4n8p73

Hair, J., Hollingsworth, C. L., Randolph, A. B., \& Chong, A. Y. L. (2017). An updated and expanded assessment of PLS-SEM in information systems research. Industrial Management \& Data Systems. https://doi.org/10.1108/IMDS-04-2016-0130

Harun, A. (2020). Analysis of Accounting Student Perceptions towards the Desire for a Career as Qualified Accountants: Case Study on Higher Education in Medan. 
Haynes, K. (2017). Accounting as gendering and gendered: A review of 25 years of critical accounting research on gender. Critical Perspectives on Accounting, 43, 110-124. https://doi.org/10.1016/j.cpa.2016.06.004

Heiat, A., Brown, D., \& Johnson, D. M. (2007). An empirical analysis of underlying factors affecting the choice of accounting majors. Journal of College Teaching and Learning, 4(8), 83-98. https://doi.org/10.19030/tlc.v4i8.1558

Herbert, I. P., Rothwell, A. T., Glover, J. L., \& Lambert, S. A. (2020). Does the changing world of professional work need a new approach to accounting education? Accounting Education, 1-25. https://doi.org/10.1080/09639284.2020.1827446

Holt, T., Burke-Smalley, L. A., \& Jones, C. (2017). An empirical investigation of student career interests in auditing using the big five model of personality. In Advances in Accounting Education: Teaching and Curriculum Innovations. Emerald Publishing Limited. https://doi.org/10.1108/S1085-462220170000020002

Hunt, S. C., Anthony, F. A., \& Intrieri, R. C. (2004). The nature and origins of students' perceptions of accountants. Journal of Education for Business, 79(3), 142-149. https://doi.org/10.3200/JOEB.79.3.142-148

Ishaque, M. (2020, January). Cognitive approach to understand the impact of conflict of interests on accounting professionals' decision-making behaviour. Accounting Forum, 44(1), 64-98. Routledge. https://doi.org/10.1080/01559982.2019.1583303

Jackling, B., \& Calero, C. (2006). Influences on undergraduate students' intentions to become qualified accountants: evidence from Australia. Accounting Education: An International Journal, 15(4), 419-38. https://doi.org/10.1080/09639280601011115

Jackling, B., De Lange, P., Phillips, J., \& Sewell, J. (2012). Attitudes towards accounting: differences between Australian and international students. Accounting Research Journal. https://doi.org/10.1108/10309611211287305

Jones, B. D., Paretti, M. C., Hein, S. F., \& Knott, T. W. (2010). An analysis of motivation constructs with first year engineering students: Relationships among expectancies, values, achievement, and career plans. Journal of Engineering Education, 319-336. https://doi.org/10.1002/j.2168-9830.2010.tb01066.x

Khattab, N., \& Modood, T. (2018). Accounting for British Muslim's educational attainment: gender differences and the impact of expectations. British Journal of Sociology of Education, 39(2), 242-259. https://doi.org/10.1080/01425692.2017.1304203

Law, P. K. (2010). A theory of reasoned action model of accounting students' career choice in public accounting practices in the post-Enron. Journal of Applied Accounting Research. https://doi.org/10.1108/09675421011050036

Malthus, S., \& Fowler, C. (2009) Perception of Accounting: a quantitative New Zealand study. Pacific Accounting Review, 2l(1), 26-47. https://doi.org/10.1108/01140580910956849

Marriott, P. R. U., \& Marriott, N. (2003). Are we turning them on? A longitudinal study of undergraduate accounting students' attitudes towards accounting as a profession. Accounting Education: An International Journal, 12(2), 113-133. https://doi.org/10.1080/0963928032000091738

Mbawuni, J., \& Nimako, S. G. (2015). Modelling Job-Related and Personality Predictors of Intention to Pursue Accounting Careers among Undergraduate Students in Ghana. World Journal of Education, 5(1), 65-81. https://doi.org/10.5430/wje.v5n1p65

Mustapha, M., \& Hassan, M. H. A. (2012). Accounting Students' Perception on Pursuing Professional Examination. International Journal of Education, 4(4), 1. https://doi.org/10.5296/ije.v4i4.1546

Ng, Y. H., Lai, S. P., Su, Z. P., Yap, J. Y., Teoh, H. Q., \& Lee, H. (2017). Factors influencing accounting students' career paths. Journal of Management Development. https://doi.org/10.1108/JMD-11-2015-0169

Omar, N. (2009). Factors influencing the diploma in accounting (DIA) students' decision to pursue professional accounting programmmes.

Owusu, G. M. Y., Obeng, V. A., Ofori, C. G., Kwakye, T. O., \& Bekoe, R. A. (2018). What explains student's intentions to pursue a certified professional accountancy qualification? Meditari Accountancy Research. https://doi.org/10.1108/MEDAR-06-2016-0065

Owusu, G. M.Y., Essel-Anderson, A., Kwakye, T. O., Bekoe, R. A., \& Ofori, C. G. (2018). Factors influencing career choice of tertiary students in Ghana. Education+ Training. https://doi.org/10.1108/ET-04-2017-0050 
Ozsoy, E. (2019). An empirical test of Herzberg's two-factor motivation theory. Маркетинг і менеджмент інновацій, 1, 11-20. https://doi.org/10.21272/mmi.2019.1-01

Pincus, K. V., Stout, D. E., Sorensen, J. E., Stocks, K. D., \& Lawson, R. A. (2017). Forces for change in higher education and implications for the accounting academy. Journal of Accounting Education, 40, 1-18. https://doi.org/10.1016/j.jaccedu.2017.06.001

Pratama, A. (2017). Why do accounting students choose a career in accountancy? An exploratory study in Bandung City, West Java, Indonesia. Review of Integrative Business and Economics Research, 6(2), 393.

Rkein, H., Issa, Z. A., Awada, F. J., \& Hejase, H. J. (2019). Impact of Automation on Accounting Profession and Employability: A Qualitative Assessment from Lebanon. Saudi Journal of Business Management, 4, 372-385.

Rocher, S., Christensen, M., \& Roy, Y. (2020). "This looks like a job for an accountant! (with good funeral insurance)": The changing roles of accountants in superhero comics from 1938 to 2018. Accounting History, 1032373220949942. https://doi.org/10.1177/1032373220949942

Said, J., Ghani, E. K., Hashim, A., \& Nasir, N. M. (2004) Perception Towards Accounting Career Among Malaysian Undergraduates. National Accounting Research Journal, 2(1), 31-42. https://doi.org/10.1108/19852510480000658

Samsuri, A. S. B., Arifin, T. R. B. T., \& Hussin, S. B. (2016). Perception of undergraduate accounting students towards professional accounting career. International Journal of Academic Research in Accounting, Finance and Management Sciences, 6(3), 78-88. https://doi.org/10.6007/IJARAFMS/v6-i3/2173

Santos, E. A. D., \& Almeida, L. B. D. (2018). To pursue a career in accounting or not: a study based on the Theory of Planned Behavior. Revista Contabilidade \& Finanças, 29(76), 114-128. https://doi.org/10.1590/1808-057x201804890

Silfi, A., \& Hamid, M. A. A. (2020). The Comparative Analysis of Personality and Beliefs About Knowledge Towards Academic Performance at Three Levels Accreditation of Universities in Indonesia: Evidence from Accounting Students in Indonesia.

Smith, G. S. (2017). The accountant: a character in literature. Meditari Accountancy Research. https://doi.org/10.1108/MEDAR-03-2015-0014

Srirejeki, K., Supeno, S., \& Faturahman, A. (2019). Understanding the Intentions of Accounting Students to Pursue Career as a Professional Accountant. Binus Business Review, 10(1), 11-19. https://doi.org/10.21512/bbr.v10i1.5232

Steadman, G., \& Huang, A. (1996) Factors influencing choice of accounting discipline - culture and gender differences. Accounting Research Journal, 9(1), 82-89.

Suan, C., Mat, N., \& Tan, L. (2012). What drives the career choice among engineers? A case in Malaysian.

Sugahara, S., \& Boland, G., (2006). Perceptions of the certified public accountants by accounting and non-accounting tertiary students in Japan. Asian Review of Accounting, 14(1/2), 149-167. https://doi.org/10.1108/13217340610729518

Sugahara, S., Hiramatsu, K., \& Boland, G. (2009). The factors influencing accounting school students' career intention to become a Certified Public Accountant in Japan. Asian Review of Accounting, 17, 5-22. https://doi.org/10.1108/13217340910956487

Tan, L. M., \& Laswad, F. (2018). Professional skills required of accountants: what do job advertisements tell us? Accounting Education, 27(4), 403-432. https://doi.org/10.1080/09639284.2018.1490189

Thing, O. G., \& Jalaludin, D. (2018). Career Path in Accounting: What are the drivers? International Academic Journal of Accounting and Financial Management, 5(2), 161-177. https://doi.org/10.9756/IAJAFM/V5I2/1810024

Ţicoia , C. F., \& Albu, N. (2018). What factors affect the choice of accounting as a career? The case of Romania. https://doi.org/10.24818/jamis.2018.01007

Tourna-Germau, E. (2006). Understanding, predicting and influencing business students' accounting career choice (Doctoral dissertation, Sheffield Hallam University,).

Trump G. W., \& Hendrickson, H. S. (1970). Job selection preferences of accounting students. The Journal of Accountancy, June, 84-86. 
Uthman, A. B., Sanni, M., \& Salami, A. A. (2019). Prospect for accounting academics: examining the effect of undergraduate students' career decision. Management \& Accounting Review (MAR), 18(3), 95-130.

Wen, L., Hao, Q., \& Bu, D. (2015). Understanding the intentions of accounting students in China to pursue certified public accountant designation. Accounting Education, 24(4), 341-359. https://doi.org/10.1080/09639284.2015.1051561

Wen, L., Yang, H. C., Bu, D., Diers, L., \& Wang, H. (2018). Public accounting vs private accounting, career choice of accounting students in China. Journal of Accounting in Emerging Economies. https://doi.org/10.1108/JAEE-09-2016-0080

Wheeler, K. G. (1983). Perception of labour market variables by college students in business, education and psychology. Journal of Vocational Behaviour, 22, 1-11. https://doi.org/10.1016/0001-8791(83)90002-7

Woasey, F. A. (2015). Factors influencing the career choice of undergraduate students in the humanities of the University of Ghana (Doctoral dissertation, University of Ghana).

Wyness, L., \& Dalton, F. (2018). The value of problem-based learning in learning for sustainability: Undergraduate accounting student perspectives. Journal of Accounting Education, 45, 1-19. https://doi.org/10.1016/j.jaccedu.2018.09.001

\section{Copyrights}

Copyright for this article is retained by the author(s), with first publication rights granted to the journal.

This is an open-access article distributed under the terms and conditions of the Creative Commons Attribution license (http://creativecommons.org/licenses/by/4.0/). 